\title{
GROTIUS' VIEW OF THE GOSPELS AND THE EVANGELISTS
}

\author{
HENK JAN DE JONGE \\ (Leiden)
}

\section{A. The Plage and Function of the Gospels in Grotius' THEOLOGY ${ }^{1}$}

It would not be entirely correct to state that Grotius' theology is founded on the Gospels.2 In his own view, the basis of Christian theology was not the written Gospels, but 'the' gospel, in the singular, that is, the Truth revealed by Christ during his earthly ministry and subsequently preached by the apostles. ${ }^{3}$

This gospel of Christ, which underlies the written Gospels, was defined by Grotius as "a new doctrine demanding a radical change of mind and conduct, and promising the remission of sins and eternal life." 4 The content of the Gospel revealed by Christ, according

1 This contribution is partly based on research done by MS MH DE LANG, research-assistant in the Faculty of theology of Leiden University She kindly allowed me to use the excursus she devoted to Grotius in her doctoral dissertation De opkomst van de hastonsche en literaire kntzek in de synoptische beschouwerng van de evangehen van Calvinn (1555) tot Gresbach (1774) (diss Leiden), Leiden 1993, pp 125-35 That the late 18th and 19th-century literary criticism of the Gospels ongmated as an apologetic reaction to the radical, almost a-historical hypercritıcısm leveled against the Gospels by the Deists, is an idea I owe to Ms De Lang This idea plays a crucial role in my assessment of Grotius as an exegete in section $\mathrm{C}$ below

2 Recent studies of Grotius' biblical exegesis include H GRaf Reventlow, "L'exegese humaniste de Hugo Grotius", in J-R Armogathe (ed), Brble de tous les temps, Vol 6, Le Grand Siecle et la Brble, Paris 1989, pp 141-54, H Graf ReventLow, "Humanistic Exegesis The Famous Hugo Grotius", in B Uffenheimer - H Graf Reventlow (edd), Creatwe Brblical Exegesis Journal for the Study of the Old Testament, Supplement Series 59), Sheffield 1988, pp 175-91, HJ DE JoNGE, "Hugo Grotius exegete du Nouveau Testament," in The World of Hugo Grotzus (1583-1645), Amsterdam/Maarssen 1984, pp 97-115, HJ DE JonGE, "Grotuus as an Interpreter of the Bible, particularly the New Testament," in Hugo Grotius A Great European, 1583-1645, Delft 1983, pp 59-65 Earlier literature on the subject is mentioned in the footnotes to the studies just mentioned

3 Hugo Grotrus, De ventate religzonas chrnstianae II,7, in OTh $\mathrm{III}$, col $36 \mathrm{~b}$ " Chrrstus, ut et sur et ahenı fatentur, novum protuht dogma", De vertate VI, 1 , in OTh III, col 94a "Monentur deinde sanctum illud dogma Christ, ut pretıosissimum thesaurum sollicite custodire, atque eam ob rem saepe legere Sacra scripta" $B W$ II, no 640 (Grotıus to P Dupuy, [May 1621 P]), p 73 "Evangelium, 1d est dogma novum perfecte a Christo revelatum, et per Apostolos per orbem totum lussum praedicari"

${ }^{4} B W$ II, no 640 (Grotius to P Dupuy [May 1621?]), p 73 "Evangelium, id est dogma novum resipiscentiam exactam deposcens, et promittens remissionem peccatorum et vitam aeternam, quod praeparatıons modo a Baptssta annuntıatum est, perfecte vero a Chrssto revelatum, et per Apostolos per orbem totum lussum prae- 
to this definition, was, first, the necessity of a radical change of life (resipuscentia), and second, the promise of eternal salvation. It is no accident that Grotus mentions the necessary change of life in the first place. The main thing in the message of Christ, according to Grotus, was the commandment of love..$^{5}$ In the teaching of Christ, as viewed by Grotius and other Christian humanists, the praxus pretatus was of prime importance. ${ }^{6}$ This is not to say that Grotıus limited the role of Christ to that of a teacher or Revealer. Christ was certainly also the one who through his expiatory death had brought about forgiveness of sins and the Atonement. ${ }^{7}$ But one could not know Christ as Saviour unless through the gospel that he himself had been the first to preach.

The primary function of the Gospels, then, is that in preserving the message of Jesus in a written form, they disclose the truth which God wanted to communicate to mankund.

In Grotius' theology, however, the Gospels have also another function. They have also to warrant the unique divne authority of the message brought by Jesus. For how can one know for certain that the gospel preached by Jesus is the exclusive Truth coming from God? To answer this question Grotius does not resort to the doctrine of the inspiration of Scripture. Many protestant theologians of the 16th and 17th centures, both Lutherans and Calvin1sts, held that the divine authority of the content of Scripture was

dicar, "In what follows I shall have to mention Grotıus' letter to Pierre Dupuy, $B W$ II, no 640 , stall more than once The autograph of this extremely important letter is kept in Paris, Bibliotheque Nationale, Fonds Dupuy 16, no 101 The letter bears no date, see L Dorez, Catalogue de la Collection Dupuy, I (nos 1-500), Parts 1899, under $\mathrm{nr}$ 16, p 20 "s(ans) d(ate), autographe (101)" Molhuysen dated it to [May 1621] because it follows a letter of 8 May 1621 in Epistolae (now no $639 \mathrm{~m}$ $B W$ ) Molmuysen, $B W$ II, p 73, n 1, rightly observed that no 640 offers no clue for dating it more precisely

5 Hugo Grotius, Annotationes in Novum Testamentum, ad Rom 157 "quum in evangelio praecipuum sit dilectio", ad Eph 14 " dilectionis, in qua est evangelı $\tau \grave{o} \pi \hat{\alpha} v "$

${ }^{6}$ For the dommant place of ethics in Grotuus' theology, see, e g, W C VAN UNNIK, "Hugo Grotius als uitlegger van het Nieuwe Testament", first pubhshed in NAKG N S 25 (1932), pp 1-48, reprinted in W C vaN UNNIK, Woorden gaan leven, Kampen 1979, pp 172-214, especially pp 182-83, G H M Posthumus Mexjcs, Hugo Grotus Meletzus swe De uns quae inter Chrstianos convenzunt Eprstola, pp 33-35, G H M Posthumus Meyjes, "Hugo de Groot's 'Meletius' (1611), His Earliest Theological Work, Rediscovered," Lias 11 (1984), pp 147-50, especially p 150 "(Grotuus) repeatedly made it clear that for him ethics was by far the most important ( )", $\imath e$, more important than dogmatics

7 This becomes of course perfectly clear from Grotıus' work De satzsfactione, Leiden 16171 See E RABBIE, Hugo Crotzus Defensio fider cathohcae De satzsfactione Chnsti adversus Fausium Socmum Senensem (Opera Theologica edited by the Grotuus Institute of the Royal Netherlands Academy of Arts and Sciences I), Assen Maastricht 1990 
secured by its being divinely inspired. In this theory the validity of the teaching of Christ and his apostles was guaranteed by the inspiration of Scripture. But Grotius preferred not to appeal to the doctrine of the inspiration, because this doctrine could not be supposed to be valid for non-Christians. ${ }^{8}$ In order to prove the exclusive truth of the teaching of Christ, Grotius used another argumentation, which he considered to be cogent for Christians and nonChristians alike. This argumentation consists of four steps, each of which derives its validity from the following step. Grotius argued as follows.

(1) The teaching of Christ must be of divine authority because he himself was a divine person ${ }^{9}$ or at least someone who spoke by God's order. ${ }^{10}$

(2) The divine nature of Christ's mission is proven by the miracles he worked and by his resurrection. ${ }^{11}$

(3) The historicity of the miracles Jesus worked and of his resurrection is beyond doubt because they are recorded by trustworthy writers. These writers include Matthew and John, direct pupils of Jesus and eyewitnesses of his ministry, and Mark and Luke who were equally well informed, Mark because he was a pupil of Peter and Luke because he collected solid information on Jesus' activity from eyewitnesses in Palestine. ${ }^{12}$

${ }^{8}$ In his De veritate religionis christianae, III,5 (OTh III, col. 51), Grotius maintains the doctrine of the inspiration of Scripture only in a few cases in which the biblical authors appear to have had knowledge which they could not have derived from experience or from tradition. This applies to (1) the visions in the book of Revelation, and (2) some passages in the Epistle to the Hebrews in which the author himself appeals to the inspiration of the Holy Ghost. That Grotius had not yet familiarized himself entirely with the rejection of the inspiration appears from his epilogue to $D e$ veritate, where he speaks of the "scriptores sacrae scripturae" as "afflatus divini pleniores." This traditional phrase is inconsistent with Grotius' rejection of the inspiration in the rest of De veritate. Grotius did not reject the inspiration only in $D e$ veritate for apologetic reasons. The same view is presupposed in his letter nr. 640 of [May 1621?] to P. Dupuy, $B W$ II, p. 73, and in the controversy with Rivet. Sec, e.g., Votum pro pace ecclesiastica, OTh III, cols. 672b-673a, "De canonicis Scripturis," where Grotius states inter alia: "A Spiritu Sancto dictari historias nihil fuit opus: satis fuit scriptorem memoria valere circa res spectatas, aut diligentia in describendis veterum commentariis."

${ }^{9}$ See Grotius, Ep. 640 (to P. Dupuy [May 1621?]), BW II, p. 73: "per quae omnia [sc. through his resurrection and ascension to heaven] apertissime filius Dei declaratus est." And some lines further down: "eius [sc. Christ's] personam a qua Evangelium suam habet auctoritatem."

10 Grotius, De veritate II,7 (OTh III, col. 36b): "Christus ... novum protulit dogma tamquam mandato divino."

11 Grotrus, De veritate II,7 (OTh III, col. 36b).

12 Grotius, De veritate III,5 (OTh III, col. 5 l a-b). 
As P.T. van Rooden has observed and J.P. Heering has demonstrated, Grotius owed the three step argumentation just mentioned for the most part to Faustus Socinus' work De auctoritate Sacrae Scrpturae (Amsterdam 15881; Stemfurt 16112; Grotius probably used G.J. Vossius' copy of the latter edition). ${ }^{13}$ Grotius himself added a fourth step:

(4) The authority of the disciples and evangelists is proven by the miracles they worked and by the miracles that took place near their graves. ${ }^{14}$

From this train of thought it becomes clear that in Grotius' view the Gospels were not only important because they preserve the content of Jesus' teaching, on which faith and theology have to be based. The Gospels have a second function. Through their stories about Jesus' miracles and bodily resurrection, the Gospels guarantee the divine authority of Jesus' message. In this manner Grotius believed he could prove the unique and divine nature of the teaching of Christ on purely historical, 'objective' grounds, without appealing to the doctrine of the inspiration of Scripture.

Summarizing the first part of this contribution, I submit that in Grotuus' theology the Gospels have a twofold function. Firstly, in those passages which present the words of Jesus, they give access to the truth God had decided to make known to man. Secondly, in their narrative parts, especially in the miracle stories, they give firm evidence that this truth is of divine authority.

${ }^{13}$ P T van ROODEN - J W Wesselius, "The Early Enlughtenment and Judaism The 'Civil Dispute' between Philippus van Limborch and Isaac Orobio de Castro (1687)," Studaa Rosenthalaana 21 (1987), pp 140-53, especially pp 151-52 with n 39, argue that Grotius" "source" was the Socinian Catechism of Rakov (1609) and that the argumentation referred to above, and used in the Catechism of Rakov, was in its turn "a logical development of Faustus Socinus' conception of the authority of the Bible Gf his 'De auctoritate Sacrae Scripturae' and 'Lectiones sacrae' in the Opera Omnza (Irenopoll [= Amstelodam], 1656) "J P HeERING, Hugo de Groot als apologeet van de christelyke godsduenst Een onderzoek van zyn geschrnft De verntate relzgroms christzanae (1640), diss Leiden, The Hague 1992, pp 118-19, argues that Grotius' De Vertate II-III is drectly dependent on Socinus' De auctoritate in the Steinfurt 1611 edition The first step of Grotius' argumentation mentioned above is discernible as a distinct step only in $\mathrm{Ep} 640$

14 Grotius, De ventate III,7 (OTh III, cols 51b-52a) This fourth step added by Grotius himself cannot be described as fortunate For it provokes inevitably the question how one can be sure that the miracles that are sard to have been performed by the apostles and to have occurred near their graves, really took place This question does not seem to have worried Grotrus That he based his rationalistic plea for the historicity of the events narrated in the Gospels and, ultımately, for the truth of the Christian religion on the more than dubious traditions about miracles on the graves of the apostles, is a surprising weakness in his apologetic work This lack of critical sense, too, shows that Grotuus belonged to the latter days of humanism, not to the dawning era of Descartes 


\section{B. Grotius' View of the Relationship between the Gospels and the. Historical Jesus}

From what precedes one might infer that according to Grotius the ministry and teaching of Jesus could reliably be reconstructed. This conclusion is correct, but it needs some qualifications.

Firstly, Grotius held that in recording Jesus' ministry none of the evangelists had retained the correct chronological order. Each of them had composed his Gospel with considerable freedom as regards order. Thus, each evangelist had arranged his material in the sequence which he himself had deemed most fit for creating a convincing and coherent narrative. Now Grotius believed that in a historical reconstruction of Jesus' career most of the narratives contained in the Gospels could be assigned their chronologically correct place. Occasionally, however, Grotius observes that the context in which a given saying of Jesus occurs in one or another Gospel cannot have been that saying's primitive setting in the life of the historical Jesus. For some of these sayings it was impossible, Grotius believed, to indicate at which point in Jesus' biography they had to be inserted. Here we find a slight touch of historical scepticism in regard to the question whether the Gospels allow a reliable historical reconstruction of Jesus' ministry.

Sayings of Jesus of which, according to Grotius, the original place in the history of Jesus' activity could not be determined any more include the following.

(a) Luke 6.39: "Can one blind man be guide to another? Will they not both fall into the ditch?" Luke combined this saying with other words of Jesus, "although," as Grotius says, "it was perhaps spoken at another time and another occasion."

(b) The dialogues recorded in Luke 9.57-58, 59-60, and 61-62. It is Luke who joined these dialogues because of their affinity in content. In reality they took place on different occasions. When precisely in Jesus' ministry each of these dialogues must be placed, cannot be ascertained.

(c) Luke 13.32: "Go and tell that fox (i.e., Herod Antipas), 'Listen: today and tomorrow I shall be casting out devils and working cures; on the third day I reach my goal"', and what follows in v. 33. Grotius took the days mentioned here to mean years. Consequently, Jesus must have spoken these words about three years before his death, not some months or weeks before he died, as Luke's Gospel suggests. But when precisely Jesus spoke the words in question cannot be ascertained any more. 
A second reservation Grotius made in regard to the reliability of a historical reconstruction of Jesus' ministry was that the evangelists as narrators were not unerring. Grotius believed that the evangelists could err in historical and geographical details. ${ }^{15}$ For in composing their Gospels they were not guided by the Holy Ghost. They simply related what they remembered as eyewitnesses or what they had heard from their informants. Grotius points out the following error in Matthew and Mark. They mention as the cause of the violent death of John the Baptist that John had criticized Herod's marriage with the former wife of his brother. ${ }^{16}$ Grotius observes that Josephus mentions a different cause for John's death, namely Herod's fear of a popular revolt that might have been elicited by John's teaching. ${ }^{17}$ In Grotius' opinion, then, Josephus' authority as an historian cannot be ignored. Consequently, the evangelists must be in error here.

Thirdly, it was perfectly clear to Grotius that the material contained in the four Gospels does not suffice to compose a more or less adequate biography of Jesus. Their content is only a selection of such material as portrays him as the Son of God. They give the divine message he brought, his teaching, and the stories about the miracles that give evidence of his authority. But they omit everything that does not contribute to present Jesus as Grod's unique Messenger. Apart from the birth-stories, the Gospels tell us nothing about Jesus' life until he was baptized, at the age of about thirty. The Gospels focus on the last two and a half years of Jesus' career. The reason of this, as Grotius correctly understood and pointed out, is that the evangelists did not intend to write history, but Gospels, which through their account of his teaching and miracles had to demonstrate that Jesus was God's Son. ${ }^{18}$

Thus, in Grotius' opinion the Gospels could be used for a historical reconstruction of Jesus' ministry except with three reservations: (1) for some sayings of Jesus it was impossible to determine at which moment they had been pronounced; (2) in a few historical and geographical details the evangelists have made a mistake; (3) the Gospels contain only a selection of material about Jesus, that is, only such material as depicts him as the authoritative Messenger of God. These three reservations, however, sum up about all the rela-

15 Grotius, Annotationes in Acta Apostolorum, ad Acts 7.3.

16 Mark 6.17-19; Matthew 14.3-4.

17 JosepHus, Antiquitates XVIII, v, 2, 118.

18 This is what Grotius argues in his letter 640 of [May 1621?] to P. Dupuy, BW II, p. 73. 
tıvism that one can discern in Grotıus' view of the historicity of the Gospels True, it must be conceded that this relatıvsm goes further than in the exegetical works of most of his contemporaries and predecessors, the more favourable exceptions being Sebastian Castello and John Calvin 19 Nevertheless, Grotius' contribution to the development of New Testament scholarship cannot be said to consist in his historical criticism of the Gospels On the whole, Grotius had great confidence in the possibility of reconstructing the ministry of Jesus $\mathrm{He}$ assumed that in such a reconstruction the texts of the Gospels could be integrated as they stood $\mathrm{He}$ consistently reasoned away discrepancies between the Gospels by means of a variety of traditional harmonizations

In short, Grotius' view of the relationship between the Gospels and the historical reality of Jesus' ministry was still rather naive In Grotius' treatment of the Gospels historical criticism does not yet play a role of great significance

\section{G An Assessment of Grotius' View of the Gospels and the EVANGELISTS}

There can be no doubt that Grotuus' exegesis of the Gospels is in several respects an impressive improvement on that of his contemporaries His main merit lies in his constant effort to explain the language and thoughts of the evangelists in light of the usage and 1deas of ancient authors Hellenustic, Greek, Hebrew, Roman, Jewish Grotius tried to recover the meaning the Gospels had had for their original readers in antiquity, and not to utlize them for underpinning a denominational theology of the seventeenth century In other words, Grotuus tried to understand the Gospels as documents of the first century $\mathrm{C} E$, not as ammunition for defending a seventeenth-century theological position The choice of illustrative material Grotius adduced to elucidate the biblical texts is often so felicitous that his Annotationes on the Gospels remain a useful commentary up to the present day

Really innovative was Grotuus' view of the evangelists as authors who were free to arrange their material in accordance with their own narrative intentions 20 This insight enabled him to explain

19 For the relativism of Castellio and Calvin in regard to the possibility of reconstructing the history behind the Gospels, see M H DL LANG, De opkomst van de histonsche en lateratre kntiek (see n 1), pp 23-32, 4346

$20 \mathrm{HJ}$ De Jonge, "Hugo Grotius exegete du Nouveau Testament" (see n 2 above), pp 10607 See also Grotrus' Annotationes in Novum Testamentum, ad Mt 266,2664 , Lk 22 63, John 6 15, Apoc 91, and Lk 316, 639, 4 21, 1332 
many a passage in terms of the specific intentions each individual evangelist had had in composing his Gospel. Equally innovative is Grotius' view of the evangelists as ordinary writers who composed their works without divine inspiration. By rejecting both verbal and direct inspiration, Grotius 'secularized' the image of the evangelists. The importance of this is that the understanding of the evangelists as independent authors made the Gospels a more attractive object for the application of the methods of philological, literary and historical research.

It testifies to Grotius' keen insight into the nature of the Gospels that he characterized them as a kind of Christological manifestos, rather than as historiography. Thus, he explained with success why they record Jesus' teaching and miracles while omitting almost all biographical material up to the moment he assumed his public ministry. ${ }^{21}$

Grotius' 'secularization' of the evangelists was beneficial to the rise of sound exegesis, but it also held a danger. It had no doubt an apologetic intention. Grotius intended to place the unique authority of the message preached by Christ on the 'objective' footing of the verifiable historicity of his miracles and resurrection, instead of on the inspiration of Scripture. Eventually, the secularization of the evangelists aimed at the reinforcement of the objective validity of the Christian religion. The danger of this apologetic search for objectivity was soon to become clear. Strikingly, it was a danger Grotius had not foreseen. Philosophical criticism of the possibility of miracles and bodily resurrection, as expressed by Spinoza and the Deists, could not but entail the rejection of the truth of the Christian religion in so far as it was based on those supernatural events.

We have mentioned several elements in Grotius' view of the Gospels that have contributed to a more historical understanding of these documents. It need not be concealed that the way Grotius viewed the Gospels also shows that he was a child of his time. Grotius remained traditional in that he did not make an issue of the historical reliability of the Gospels' report of Jesus' words and deeds. Grotius believed that the reconstruction of Jesus' teaching

21 Grotrus, Ep. 640, BW II, p. 73. Grotius' view on the Gospels as a kind of "Christological manifestos," which because of that specific character offered only such material as could serve to present Jesus as the Son of God, did not remain unnoticed in the eighteenth century. Grotius' letter on the subject, now no. 640 in $B W$ II, pp. 73-74, is quoted in extenso by J.A. FABRIarus, Codex Apocryphus Novi Testamenti, Pars III, Hamburg 1719, pp. 412-15, as an excursus under the heading "Quare Evangelistae nihil fere de Christo commemorent ante annum a nativitate eius tricesimum. Hugo Grotius Epist. CXLIII ad Petrum Pateannum [sic]." 
and activity that he thought could be made on the basis of a harmonization of the four Grospels, was a farthful description of what Jesus taught and did. Grotius did not yet realize that the Gospels might include ideas and material that originated in the circle of Jesus' followers, in the Jesus movement after his death, and in early Christian communities. Grotius was also very traditional in the way he consistently tried to reconcile the different versions of corresponding stories in two or more Gospels by arguing away the discrepancies.

Moreover, Grotius naively assumed that h1s reconstruction of Jesus' teaching could serve immediately as theology of the seventeenth century. For that is the supposition of the Annotationes on the New Testament. In this work Grotius wanted to clarify the meaning the message of Christ and the apostles had had for the original audience in the first centuries C.E. But Grotius supposed this historical meaning also to be valid for his seventeenth-century audience.

Finally, for a correct assessment of Grotius as an interpreter of the Gospels, it is of vital importance to take due note of the fact that Grotius kept a firm belief in the possibility of a historical reconstruction of Jesus' ministry and in the historical reliability of such a reconstruction. This is important, since the course which the critical study of the Gospels as a scholarly discipline was to take was via the radical rejection of the Gospels' historicity by the Deists (ca. 1670 - ca. 1750$)^{22}$ to the valuable literary criticism of the late eighteenth century. ${ }^{23}$ Obviously, the loss of faith in the historicity of the Gospels was necessary for the sound literary-critical theories concerning the interrelationships of the Gospels to emerge. I am referring here to the Proto-Gospel Hypothesis of Lessing and the Two Gospel Hypothesis of Griesbach.24 These theories tried to ex-

22 H Grar Reventlow, Bibelautontat und Geist der Moderne, Gottmgen 1980, HJ DE Jonge, Van Erasmus tot Rermarus, Leiden 1991, 1dem, "The Loss of Faith in the Historicity of the Gospels H S Reimarus (ca 1750) on John and the Synoptics," in A Denaux (ed), Fohn and the Synoptrcs [Bibliotheca Ephemeridum Theologicarum Lovaniensium 101], Louvain 1992, pp 409-22

$23 \mathrm{MH}$ de LaNG, "Literary and Historical Critıcism as Apologetıcs Biblıcal Scholarship at the End of the Eighteenth Century," NAKG/Dutch Revere of Church Hestory N S 72 (1992), pp 149-65, M H DE LANG, "Grospel Synopses from the 16 th to the 18th Centuries and the Rise of Literary Criticism of the Gospels," in C Focant (ed), The Synoptzc Gospels Source Cntzcusm and the New Luterary Cntzcusm [B1bliotheca Ephemeridum Theologicarum Lovaniensium 110], Louvain 1993, pp $599-607$

24 On these theories, see, eg, W G KummLl, Enteetung in das Neue Testament, Heldelberg $1978^{19}$, pp 19 (on Lessing's Proto-Gospel Hypothesis, "Urevangelıumshypothese") and 21-22 (on Griesbach's Two Gospel Hypothesis) 
plain the form of the Gospels by assuming that they are literarily dependent on earlier sources or on each other. The rise of a sound literary criticism of the Gospels obviously needed the stimulus of a radical historical scepticism. For all his merits for biblical exegesis, then, Grotius hardly contributed to the development of the historical criticism of the Gospels. Grotius' work on the Gospels is the climax of the era of humanistic exegesis, it is not the beginning of a new era. 